\title{
Leadership Styles and Retention of Teachers in Private Primary Schools in Bushenyi-Ishaka Municipality, Uganda
}

\author{
Wilson Mugizi*, Grandford Tumuhaise, Bulhan Samanya, Augustina Ogaga Dafiewhare \\ Kampala International University Western Campus, Kampala, Uganda \\ Email: *wilsonmugizi@kiu.ac.ug
}

How to cite this paper: Mugizi, W., Tumuhaise, G., Samanya, B., \& Dafiewhare, A.O. (2019). Leadership Styles and Retention of Teachers in Private Primary Schools in Bushenyi-Ishaka Municipality, Uganda. Open Journal of Leadership, 8, 167-187. https://doi.org/10.4236/ojl.2019.84009

Received: September 27, 2019

Accepted: December 6, 2019

Published: December 9, 2019

Copyright $\odot 2019$ by author(s) and Scientific Research Publishing Inc. This work is licensed under the Creative Commons Attribution International License (CC BY 4.0).

http://creativecommons.org/licenses/by/4.0/

\begin{abstract}
This study examined the relationship between the leadership styles and retention of teachers in Bushenyi-Ishaka Municipality, Uganda. Leadership styles were studied in terms of transformational, transactional and laissez-faire on a sample of 107 primary school teachers. The study adopted the correlational design and data were collected using a self-administered questionnaire. Data analysis involved descriptive and inferential analyses. Descriptive results revealed that teacher retention was good. Nevertheless, while the use of transformational leadership was also good, there was moderate use transactional leadership and low use of laissez-fair leadership was lowly used. Regression analysis revealed that transformational leadership had a positive significant relationship with retention of teachers. Nevertheless, transactional leadership had a positive but insignificant relationship with retention of teachers while laissez-faire leadership had a negative and insignificant one. Therefore, it was concluded that transformational leadership is imperative for retention of teachers, transactional leadership is not the most probable leadership style for retention of teachers, and laissez-faire leadership is not a desirable leadership style. The recommendations of the study are that head teachers should make it a priority to be transformational in their leadership, should limit their use of transactional leadership style, and avoid laissez-faire leadership.
\end{abstract}

\section{Keywords}

Leadership, Laissez-Faire, Retention, Teachers, Transformational, Transactional

\section{Introduction}

Teachers are important as far as students learning and the development of hu- 
man capital in them are concerned (Burgess, 2016; Darling-Hammond, Flook, Cook-Harvey, Barron, \& Osher, 2019). Researchers have reported that quality teachers have a positive effect on students' accumulation of human capital and achievement (Chambers \& Hill, 2015). Teachers are the principal human resource in any education system. Therefore, as a human resource input, as the role of workers in production is similar to the role of machinery and other forces of production, teachers are required for the process of producing student learning outcomes (Ginsburg, 2017). Teachers not only have an influence on test scores of students but also their social and emotional development, their behaviours, knowledge and critical thinking development (Blazar \& Kraft, 2017). Therefore, it is imperative for schools to retain high-quality teachers. However, globally low retention of teachers in schools is a big challenge. For instance, in the United States, primary teaching experiences high and increasing rates of annual departures of teachers from schools and teaching altogether. Annual teacher turnover is estimated to be close to $16 \%$ at the national level and reaches $24 \%$ for hard-to-staff schools (Sutcher, Darling-Hammond, \& Carver-Thomas, 2016). In the UK, $9.2 \%$ teachers in $2010-11$ left and the number increased to $9.9 \%$ in 2016-17. For the new entrants, $22 \%$ of those who joined in 2015 had left by November 2016 (Foster, 2018).

In Africa, the situation is grave with a survey on the majority of education unions (60 per cent) of teachers in sub-Saharan Africa revealing that attrition rate of primary teachers was at $44 \%$ which created serious shortages of teachers (Symeonidis, 2015). In Uganda, teacher attrition rate from government aided primary schools was reported at 4.0\% (Ministry of Education and Sport [MoES], 2013). Despite the low attrition rate in government aided primary schools, a report compiled by UNESCO revealed that only $16 \%$ of the teachers aspired to stay implying that $84 \%$ primary teachers in government aided primary schools wanted to quit. The report found out that $47 \%$ of teachers were dissatisfied with their job, 59\% would not have wanted to stay in the profession if they were to start their career anew and 37\% the teachers wished to resign within a year (Anguyo, 2014). However, attrition rate for teachers' attrition in private schools was unavailable but had to be much higher given lesser job security in the schools (MoES, 2013). Owing to lack of evidence on retention of teachers in private primary schools in Uganda, this study examined retention of teachers in private schools in Uganda. In particular, the study examined the relationship between the leadership styles employed of head teachers and retention of teachers due to the fact that while there were head teachers charged with proving leadership in the schools they seemed not to be effective in inspiring teachers (Tibagwa, Onen, \& Oonyu, 2016). Possibly, that is why there was low retention of teachers. The researchers' conviction was that if head teachers in the private primary schools appropriately selected their leadership styles, they would be in position to influence retention of teachers. Therefore, seeking to establish the extent of leadership styles employed by head teachers, the following hypotheses were tested:

$\mathrm{H}_{1}$ : There is a relationship between transformational leadership and retention 
of teachers.

$\mathrm{H}_{3}$ : There is a relationship between laissez faire and retention of teachers.

$\mathrm{H}_{2}$ : There is a relationship between transactional leadership and retention of teachers.

Concept of Retention of Teachers. Employee retention is concerned with keeping or encouraging employees to remain in an organisation for life time or a maximum period of time (Kossivi, Xu, \& Kalgora, 2016). Employee retention is a technique adopted by organisations to maintain an effective workforce and at the same time meet operational requirements (Mehta, Kurbetti, \& Dhankhar, 2014). Implementing a retention process helps organisations to encourage their employees to remain for the maximum period of time beyond (Stillo \& Furxhi, 2016). Every organisation must treat its employees as ends but not means to ends because they add value to the organisation as they are the greatest asset. Therefore, long-term health and success of any organisation depend upon the retention of key employees (Deshwal, 2015). However, retaining talented employees is becoming challenging than ever. This challenge is not only a problem for profit-oriented organisations but also non-profit organisations such as schools are facing the dilemma of retaining capable and qualified teachers. Availability of jobs with higher rewards and the environment on the local scene and abroad are pushing organisations to review their employee retention strategies. Such strategies have to ensure that organisations create an environment appropriate for retention of employees (Akhtar, Aamir, Khurshid, Abro, \& Hussain, 2015).

Studies suggest that retention of teachers is important as far as performance of schools and students is concerned. For instance, Dolton and Newson (2003) in an exploration of the relationship between teacher turnover and school performance reported that high levels of teacher turnover had detrimental effects on pupil progress and achievement. Özoglu (2015) in an investigation on mobility-related teacher turnover and the unequal distribution of experienced teachers in Turkey found out that teacher turnover had far-reaching negative consequences across school-wide performances and processes. Ronfeldt, Loeb and Wyckoff (2013) in analysis of the harm teacher turnover had on student achievement found out that turnover had disruptive and harmful effects on student achievement. The findings of the studies above revealing that turnover of teachers negatively affected schools and students' performance implied that retention of teachers had beneficial effects on school and student performance. On the other hand, Rodríguez (2009) in a study on teacher retention and student achievement revealed that teacher retention significantly improved achievement of students. Owing to the importance of retention of teachers, this study sought to establish its antecedents looking at leadership styles.

Concept of Leadership Styles. The concept of leadership is as old as mankind but the evolutionary origins of leadership styles can be traced back to the seminal work of Lewin, Lippit and White (1939) in which they identified three main styles of leadership that are authoritarian, democratic and laissez-faire 
(Moorosi \& Bantwini, 2016). Authoritarian leadership style describes a leader who asserts strong authority and control over subordinates and demands absolute obedience from them. Leaders who are highly authoritarian demand their subordinates to achieve the best performance but make all the important decisions for team (Wang \& Guan, 2018). Democratic leadership style is a leadership behaviour by which the leader promotes discussion with subordinates, accepts their views and suggestions, consults them in decision making and motivates them to participate in the running of the institution in a cooperative manner (Hornáčková, Hálová, \& Nechanická, 2015). The laissez-faire leadership style involves non-interference policy, allows complete freedom to all workers and has no particular way of attaining goals (Junarso, 2009). However, since the 1980s and 1990s, there was a shift by a substantial number of leadership researchers in studying new types of styles. The researchers sought to identify effective leadership styles that inspire followers and nurture their ability to contribute to the organisation (Eagly, Johannesen-Schmidt, \& Van Engen, 2003). Such first new leadership style was proposed by Burns in 1978 which delineated a type of leadership that he labelled transformational (Day \& Antonakis, 2012). Burns followed by other researchers such as Bass (1998) and Avolio (1999) contrasted transformational leadership style with transactional leader style. The transactional leadership style was described as involving a more conventional sense of clarifying subordinate responsibilities, rewarding them for meeting objectives, and correcting them for failing to meet objectives (Giorgi, Shoss, \& Di Fabio, 2017). According to Eagly et al. (2003), in addition to transformational and transactional leadership styles, Avolio in 1999 and Bass in 1998 distinguished a laissez-faire style which is a leadership style marked by a general failure to take responsibility for managing. This study investigated the relationship of the three new leadership styles with retention of teachers.

Theoretical Review. The transformational and transactional leadership theories propounded by Burns in 1978 and later further developed by Bass (1985) were the basis for this study. The Transformational Leadership Theory suggests that transforming leadership is a relationship of mutual stimulation and elevation that converts followers into leaders and may convert leaders into moral agents (Krishnan, 2012). The leader may transform a follower's self-interest, increase the confidence of followers, elevate followers' expectations, and heighten the value of the leader's intended outcomes for the follower (Gosling \& Jones, 2012) such as retention. Transformational leadership has four components; idealised influence, individual consideration, intellectual stimulation and inspiration (Cetin \& Kinik, 2015). On the other hand, the Transactional Leadership Theory emphasises the importance of the relationship between leader and followers, focusing on the mutual benefits derived from a form of "contract" through which the leader delivers such things as rewards or recognition in return for the commitment or loyalty of the followers (De Bono, Remme, \& Jones, 2008).

Transactional leadership Theory emphasises the role of rewards as the motive 
for achieving results and punishment as a motive to ensure adherence to the goal to be achieved. Transactional leaders recognise, the actions their subordinates must take in order to achieve outcomes, and develop agreements with them, which make clear what they were received, if they do something right and what will happen if they do something wrong (Waldman, Ramirez, House, \& Puranam, 2001). The Transformational Leadership Theory suggests that when the leader transforms followers' self-interest, increases their confidence, elevates their expectations, encourages behavioural change and motivates others to higher levels of personal achievement hence they are likely to stay on their jobs. On the other hand, the transactional leadership theory proposes that when a leader develops agreements with employees that make clear what they receive if they do something right and what will happen if they do something wrong, they are likely to stay. These two theories were the basis for investigating the relationship between leadership styles and retention of teachers.

Transformational Leadership and Retention of Teachers. Transformational leadership is a style of leadership by which the leader transforms the basic values, beliefs and attitudes of followers and inspires the followers to exhibit a performance greater than their own expectations. With this style of leadership, the leader concentrates on making employees more involved in achieving their organisational targets (Gözükara \& Şimşek, 2015). The transformational leader moves followers beyond pure self-interest and the leader changes the organisation's culture by realigning it with a new vision and a revision of its shared assumptions, values, and norms (Lindgreen, Palmer, Wetzels, \& Antioco, 2009). A transformational leader fundamentally changes the values, goals and aspirations of followers who adopt his/her values and in the end perform their work because it is consistent with values and not because they expect rewards (Rothfelder, Ottenbacher, \& Harrington, 2012). Transformational leadership involves idealised influence (attributed); idealised influence (behaviour); inspirational motivation; intellectual stimulation; and individualised consideration (Kanste, Miettunen, \& Kyngäs, 2007). Transformational leaders seek new ways of working, seek opportunities in the face of risk, prefer effective answers to efficient answers, and are less likely to support the status quo. Transformational leaders do not merely react to environmental circumstances but attempt to shape and create them (Griffin, 2013).

Idealised influence (attributed) is about the leader demonstrates qualities that motivate respect and pride from association with him or her by the subordinates (Eagly, Johannesen-Schmidt, \& Van Engen, 2003). Idealised influence (behaviour) explains the degree to which the supervisor is perceived as espousing important values, beliefs, and a sense of mission (Kanste et al., 2007). The leader communicates values, purpose, and importance of organisation's mission (Eagly et al., 2003). Inspirational motivation relates to the leader providing followers with a clear sense of purpose that is energising, becoming a role model for ethical conduct and making subordinates identify with and his or her articulated vision (Lindgreen et al., 2009). Intellectual stimulation concerns the leader pro- 
moting new ways of thinking about problems or doing things in the subordinates and encouraging them to participate into problem identification and idea generation (Xenikou, 2017). Individualised consideration is the extent to which the leader focuses on understanding the needs of each follower and works continuously to get them to develop to their full potential (Lindgreen et al., 2009). Studies (e.g. Caillier, 2016; Green, Miller, \& Aarons, 2013; Gul, Ahmad, Ur Rehman, Shabir, \& Razzaq, 2012; Gyensare, Olivia Anku-Tsede, Sanda \& Okpoti, 2016; Sahu, Pathardikar \& Kumar, 2018; Wells \& Peachey, 2011) made findings pointing to the relationship between the transformational leadership style and employee retention. For instance, Caillier (2016) reported a direct negative association between transformational leadership and turnover intentions.

Green et al. (2013) found out that transformational leadership was negatively related to turnover intention. Gul et al. (2012) identified a negative insignificant association between transformational leadership styles and turnover intentions. Gyensare et al. (2016) established that transformational leadership had a negative and insignificant impact on employee turnover intention. Sahu et al. (2018) in their examination of the relationship between transformational leadership and intention to leave reported that transformational leadership style directly negatively influenced employee intention to leave. Wanga and Yen (2014) found out that transformational leadership style was positively related to turnover intentions. Wells and Peachey (2011) revealed a direct negative relationship between transformational and voluntary organizational turnover intentions. The literature above suggests that scholars had expended significant effort to relate transformational leadership and retention of teachers. However, all the studies looked at retention in its opposite by studying employee turnover. This conceptual gap made it imperative for this study to investigate retention directly and how it was influenced by head teachers' level of use of transformational leadership style.

Transactional Leadership and Retention of Teachers. Transactional leadership also called managerial leadership is a style of leadership in which the leader promotes compliance of his followers through both rewards and punishments (Srivastava, 2018). Transactional leadership is an exchange-based relationship where self-interest is dominant. Transactional leaders work within their organisation's culture and follow existing rules, procedures, and operative norms (Lindgreen et al., 2009). Transactional leaders use reward and punishments to gain compliance from their followers. Transactional leadership focuses on the role of supervision, organisation, and group performance. Transactional leaders tend to be directive and action-oriented (Dell'Aquila, Marocco \& Ponticorvo, 2016). Transactional leadership focuses on the basic functions of management, control, organisation and short-term planning. Transactional leadership is based on the assumption that employees are motivated by the best system of rewards and punishments. Transactional leaders are focused on standards, policies and procedures (Nikezić, Purić, \& Purić, 2012). Transactional leadership comprises of two aspects namely, contingent rewards and active management-by-exception. 
Contingent reward explains the leader's emphasis on clarifying the role and task requirements for subordinates as well as the performance criteria and the rewards upon accomplishing desired goals (Xenikou, 2017).

Active management-by-exception is about the leader being much committed to actively searching for subordinate mistakes (Kanste et al. 2007). With management-by-exception, leader focuses on monitoring task execution for any problems that might arise and correcting those problems to maintain current performance levels (Lindgreen et al., 2009). A number of studies (Gul et al., 2012; Long, Thean, Ismail, \& Jusoh, 2012; Maaitah, 2018; Siew, 2017; Sithole \& Sudha, 2014) have been done on transactional leadership and employee retention. Gul et al. (2012) reported that the association between leadership styles and turnover intentions was negative and insignificant. Maaitah (2018) found out that the relationship between transactional leadership and employee turnover intention was positive and significant. Siew (2017) revealed that the association between the transactional leadership style and turnover intention was negative and insignificant. Long et al. (2012) indicated that the relationship between transactional leadership styles and employees' turnover was negative and insignificant. Sithole and Sudha (2014) revealed that there was a positive relationship between the transactional leadership style and employee turnover intentions. The literature above showed that there was significant effort by scholars to relate transactional leadership and retention of employees. However, while all the other studies indicated a negative relationship between transactional leadership and retention of employees, studies (Maaitah, 2018; Sithole \& Sudha, 2014) did not concur that transactional leadership negatively related to employee retention. These controversial results suggest an empirical gap that made it necessary to further test the relationship between transactional leadership and retention of teachers in the context of schools in Uganda.

Laissez-Faire Leadership and Retention of Teachers. Laissez fair leadership refers to the leadership style by which the leader exhibits frequent absence and lack of involvement in the organisation's activities during critical junctures (Eagly et al., 2003). Also known as passive management-by-exception or hands-off style explains a kind of leader that does not get involved in his or her work unless problems attract the leader's attention. The leader provides little or no direction and gives employees as much freedom as possible (Kanste et al., 2007). Such leaders tend to react only after problems have become serious to take corrective action, and often avoid making any decisions at all (Lindgreen et al., 2009). Laissez-Laissez-faire leaders live and work with whatever structure they find in place without any suggestions or criticisms. They only get involved in setting goals and objectives only when necessary and required. The leader shuns decision-making as much as possible and would even like to avoid communication but communicates only when needed. Employee development is not a concern of the leader under this style of leadership (Puni, Agyemang \& Asamoah, 2016). Some scholars (Onsiro, Namatovu, \& Babu, 2016; Puni, Agyemang, \& Asamoah, 
2016; Wanga \& Yen, 2014) have related laissez fair leadership and employee retention. Puni et al. (2016) reported that laissez faire leadership style indicated a significantly negative relationship with turnover intentions. Onsiro et al. (2016) found out a positive correlation between laissez faire leadership style and staff retention. Wanga and Yen (2014) established that passive (laissez faire) leadership style was negatively related to turnover intentions. While the studies above indirectly and directly showed that laissez-laissez-faire positively related to retention of employees, literature search revealed limited studies had been carried out the relationship between laissez faire and retention of employees. This thus made it necessary for this study to further test the relationship between transactional leadership and retention of teachers in the context of schools in Uganda.

\section{Methods}

Sample and Procedure. The sample involved 107 primary school teachers working in private schools in Bushenyi-Ishaka Municipality in South Western Uganda. The sample was drawn from all the 11 private primary schools in the Municipality. The teachers included subject teachers, class teachers and head of departments. The aforementioned respondents were considered to be the critical units of analysis for the study because of the assumption that they could easily provide their perceptions on the leadership styles used by head teachers in schools as they experienced it since they were active teachers in those schools. The study adopted the correlational and cross-sectional designs in a survey on primary teachers. The correlational design helped in relating leadership styles to retention of teachers. The cross-sectional design permitted obtaining useful data in a relatively short period of time. The study employed simple random sampling a technique by which the respondents were selected at random and entirely by chance. This gave each individual teacher an equal chance of being included in the sample enabling collection of data that produced findings that can be generalised. The researchers personally collected data and throughout the whole process of data collection and analysis, they remained ethical. Ethical considerations included obtaining informed consent from the respondents, ensuring anonymity, confidentiality, respect for privacy and honesty by making sure that data presentation, analysis and interpretation of the findings were strictly based on the data collected.

Instrument. This correlational study was a survey involving collection of data using a self-administered questionnaire (SAQ). The SAQ comprised sections namely A, B and C. Section A was on the background characteristics of the respondents with questions on gender, age, marital status, the highest level of education attained and working experience. The question items in section A were on background characteristics scaled using the nominal scale. Section B was on the dependent variable (retention of teachers) and section $\mathrm{C}$ on the independent variable (leadership styles) with items adopted from instruments used by earlier 
scholars. Section B comprised question items on a unidimensional concept of teacher retention (11 items $\alpha=0.91$ ) from Kyndt (2009). Section C on leadership styles covered the three dimensions of leadership styles that were transformational leadership (19 items $\alpha=0.80$ ) from Kanste et al. (2007), transactional leadership (8 items, 4 items $\alpha=0.84 \& 4$ items $\alpha=0.844$ ) from Kanste et al. (2007) and Ismail, Mohamad, Mohamed, Rafiuddin and Zhen (2010) respectively and Laissez-faire leadership ( 8 items $\alpha=0.85$ ) from (Kanste et al., 2007). The question items in sections B and $\mathrm{C}$ were scaled using the five-point Likert scale from a minimum of 1 for the worst case scenario (strongly disagree) to a maximum of 5 which was the best case scenario (Strongly agree).

Data Management and Analysis. The data were processed by coding all the questionnaires, entering the data into the computer using the Statistical Package for Social Sciences (SPSS), summarising them using frequency tables and editing them to remove errors. Since the study adopted the quantitative approach, quantitative research methods were used to establish the validity and reliability of the data collected using a questionnaire. The validities of retention of teachers, and leadership styles in terms of transformational, transactional and laissez-faire leadership were tested using Factor Analysis. Reliability tests for the constructs were done using Cronbach Alpha $(\alpha)$. Data analysis involved descriptive, correlation and regression analyses. The Statistical Package for Social Sciences (SPSS) was used in carrying out analysis of data.

\section{Results}

Demographic Characteristics. The findings in Table 1 on demographic characteristics of the teachers showed that the model percentage $(58.9 \%)$ was of males, aged 20 - 30 years (47.7\%), married (65.4\%), possessed certificates $(56.1 \%)$ and with experience of less than 5 years (54.2\%).

Retention of Teachers. The concept of retention of teachers (RT) was studied as a unidimensional concept comprising of 11 items. The results on retention of teachers included frequencies, percentages, and means. The results also included validity (factor loadings) and reliability (Cronbach's alphas $[\alpha]$ ) test results. Factor loadings and Cronbach's alphas indicated the accuracy and interrelatedness of the items measuring the construct of retention of teachers. The results on retention of were as presented in Table 2.

The results in Table 2 showed that retention of teachers (RT) was rated as being good (mean $=3.53$ corresponding to agreed). Factor Analysis showed that the component of retention of teachers could be reduced to four factors, with eigenvalues of $3.336,1.366,1.284$ and 1.012. Collectively, the factors explained over $63 \%$ of the joint variation in the respective items constituting the factor of retention of teachers. With a factor loading of at least 0.5 considered strong (Coetzee, Marx \& Potgieter, 2017), the results in Table 2 suggested that all the items loaded highly on the corresponding factor. The Cronbach's alpha of 0.729 was above the benchmark $=0.70$ (Tavakol \& Dennick, 2011). Therefore, the 
Table 1. Background characteristics.

\begin{tabular}{|c|c|c|c|}
\hline Item & Categories & Frequency & Percent \\
\hline \multirow{3}{*}{ Gender } & Male & 63 & 58.9 \\
\hline & Female & 44 & 41.1 \\
\hline & Total & 107 & 100.0 \\
\hline \multirow{6}{*}{ Age Groups in Years } & Below 20 years & 2 & 1.9 \\
\hline & 20 - 30 years & 51 & 47.7 \\
\hline & $30-40$ years & 33 & 30.8 \\
\hline & 40 - 50 years & 15 & 14.0 \\
\hline & 50 years and above & 6 & 5.6 \\
\hline & Total & 107 & 100.0 \\
\hline \multirow{5}{*}{ Marital Status } & Single, never married & 31 & 29.0 \\
\hline & Married & 70 & 65.4 \\
\hline & Widowed & 5 & 4.7 \\
\hline & Divorced & 1 & 0.9 \\
\hline & Total & 107 & 100.0 \\
\hline \multirow{5}{*}{$\begin{array}{l}\text { Highest Level of } \\
\text { Education }\end{array}$} & Certificate & 60 & 56.1 \\
\hline & Diploma & 41 & 38.3 \\
\hline & Bachelor's degree & 4 & 3.7 \\
\hline & Postgraduate qualifications & 2 & 1.9 \\
\hline & Total & 107 & 100.0 \\
\hline \multirow{4}{*}{ Working Experience } & Less than 5 years & 58 & 54.2 \\
\hline & $5-10$ years & 31 & 29.0 \\
\hline & 10 years and above & 18 & 16.8 \\
\hline & Total & 107 & 100.0 \\
\hline
\end{tabular}

Table 2. Means, factors loadings and Cronbach's Alphas on components for retention of teachers.

\begin{tabular}{|c|c|c|c|c|c|c|}
\hline \multirow{2}{*}{$\begin{array}{l}\text { Retention } \\
\quad(\mathrm{RT})\end{array}$} & Means $(\bar{x})$ & \multicolumn{4}{|c|}{ Factors Loadings } & \multirow{2}{*}{ Alpha ( $\alpha)$} \\
\hline & (Overall $\bar{x}=3.53)$ & 1 & 2 & 3 & 4 & \\
\hline RT1 & 3.63 & 0.857 & & & & 0.729 \\
\hline RT2 & 3.32 & 0.633 & & & & \\
\hline RT3 & 3.49 & 0.625 & & & & \\
\hline RT4 & 3.42 & 0.621 & & & & \\
\hline RT5 & 3.50 & & 0.828 & & & \\
\hline RT6 & 3.62 & & 0.789 & & & \\
\hline RT7 & 3.55 & & 0.607 & & & \\
\hline RT8 & 4.34 & & & 0.878 & & \\
\hline RT9 & 3.50 & & & 0.571 & & \\
\hline RT10 & 3.48 & & & & 0.728 & \\
\hline RT11 & 3.00 & & & & 0.584 & \\
\hline Eigenvalue & & 3.336 & 1.366 & 1.284 & 1.012 & \\
\hline$\%$ Variance & & 30.328 & 12.420 & 11.672 & 9.204 & \\
\hline
\end{tabular}


items measuring retention of teachers were reliable measures.

Leadership Styles. The concept of leadership styles was conceived as comprising of three leadership styles that were namely; transformational (TL), transactional (TR) and laissez-faire leadership (LL). The results for the three leadership styles included frequencies, percentages and means. For each leadership style, factor loadings and Cronbach's alpha (a) results were presented showing the validity and reliability of the results. The results in Table 3 showed that teachers rated use of transformational leadership styles as good (mean = 3.79 [agreed]), transactional leadership as moderate (mean $=3.21$ [undecided]) and laissez-fair leadership as poor (mean 2.26 [disagreed]). Factor Analysis suggested that the items for transformational leadership could be reduced only five factors, with the factors having eigenvalues of 6.102, 1.400, 1.258, 1.13 and 1.035. Together, the four factors explained over $64 \%$ of the joint variation in the respective items constituting transformational leadership. Items for transactional leadership could be reduced to only two factors with the factors having eigenvalues of 2.722 and 1.827. Combined, the two factors explained over $56 \%$ of the joint variation in the respective items constituting transactional leadership. Also, items for laissez-faire leadership could be reduced to only two factors with the factors having eigenvalues of 2.970 and 1.243. Collectively, the two factors explained over $60 \%$ of the joint variation in the respective items constituting the factor of laissez-faire leadership. Considering a factor loading of at least 0.5 strong, Table 3 implied that each item loaded highly on the corresponding factor. Therefore, all the items were valid measures of the respective leadership styles (transformational, transactional and laissez-faire leadership). The Cronbach's alphas $=0.863,0.790$ and 0.813 for the respective components of leadership styles were above the benchmark of 0.7. This meant that the items for the three leadership styles were reliable measures.

Table 3. Means, factors loadings and Cronbach's Alphas on components for leadership styles.

\begin{tabular}{|c|c|c|c|c|c|c|c|}
\hline \multirow{2}{*}{$\mathrm{TL}$} & Means $(\bar{x})$ & \multicolumn{5}{|c|}{ Factors Loadings } & \multirow{2}{*}{ Alpha $(\alpha)$} \\
\hline & $($ Overall $\bar{x}=3.79)$ & 1 & 2 & 3 & 4 & 5 & \\
\hline TL1 & 3.74 & 0.724 & & & & & 0.873 \\
\hline TL2 & 3.79 & 0.696 & & & & & \\
\hline TL3 & 3.97 & 0.620 & & & & & \\
\hline TL4 & 3.70 & 0.619 & & & & & \\
\hline TL5 & 4.09 & 0.588 & & & & & \\
\hline TL6 & 3.69 & & 0.715 & & & & \\
\hline TL7 & 3.45 & & 0.657 & & & & \\
\hline TL8 & 4.13 & & 0.633 & & & & \\
\hline TL9 & 3.91 & & 0.715 & & & & \\
\hline
\end{tabular}




\section{Continued}

\begin{tabular}{|c|c|c|c|c|c|c|c|}
\hline TL10 & 3.26 & & & 0.698 & & & \\
\hline TL11 & 4.01 & & & 0.697 & & & \\
\hline TL12 & 3.83 & & & 0.647 & & & \\
\hline TL13 & 4.02 & & & & 0.804 & & \\
\hline TL14 & 3.62 & & & & 0.534 & & \\
\hline TL15 & 3.49 & & & & & 0.785 & \\
\hline TL16 & 3.78 & & & & & 0.619 & \\
\hline TL17 & 3.95 & & & & & 0.578 & \\
\hline Eigenvalue & & 6.102 & 1.400 & 1.258 & 1.132 & 1.035 & \\
\hline$\%$ Variance & & 35.892 & 8.233 & 7.401 & 6.658 & 6.088 & \\
\hline \multirow{2}{*}{ TR } & Means $(\bar{x})$ & \multicolumn{5}{|c|}{ Factors Loadings } & \multirow{2}{*}{ Alpha $(\alpha)$} \\
\hline & $($ Overall $\bar{x}=3.21)$ & 1 & 2 & 3 & 4 & & \\
\hline TR1 & 3.12 & 0.823 & & & & & \multirow[t]{10}{*}{0.718} \\
\hline TR2 & 3.36 & 0.749 & & & & & \\
\hline TR3 & 2.73 & 0.680 & & & & & \\
\hline TR4 & 2.85 & 0.620 & & & & & \\
\hline TR5 & 3.55 & 0.528 & & & & & \\
\hline TR6 & 3.33 & & 0.831 & & & & \\
\hline TR7 & 3.51 & & 0.830 & & & & \\
\hline TR8 & 3.24 & & 0.801 & & & & \\
\hline Eigenvalue & & 2.722 & 1.827 & & & & \\
\hline$\%$ Variance & & 34.025 & 22.843 & & & & \\
\hline \multirow{2}{*}{$\mathrm{LL}$} & Means $(\bar{x})$ & \multicolumn{5}{|c|}{ Factors Loadings } & \multirow{2}{*}{ Alpha $(\alpha)$} \\
\hline & $($ Overall $\bar{x}=2.26)$ & 1 & 2 & & & & \\
\hline LL1 & 2.54 & 0.849 & & & & & 0.768 \\
\hline LL2 & 2.32 & 0.836 & & & & & \\
\hline LL3 & 2.98 & 0.653 & & & & & \\
\hline LL4 & 2.05 & 0.567 & & & & & \\
\hline LL5 & 1.98 & & 0.832 & & & & \\
\hline LL6 & 2.05 & & 0.783 & & & & \\
\hline LL7 & 1.91 & & 0.627 & & & & \\
\hline Eigenvalue & & 2.970 & 1.243 & & & & \\
\hline$\%$ Variance & & 42.435 & 17.761 & & & & \\
\hline
\end{tabular}

Leadership Styles and Retention of Teachers. To establish the level of the relationship between leadership styles and retention of teachers, at a preliminary level, a correlation analysis was done. The results were as presented in Table 4 .

The results in Table 4 suggest that of the three leadership styles, only two that 
were transformational $(\mathrm{r}=0.582, p=0.000<0.05)$ and transactional $(\mathrm{r}=0.269$, $p=0.009<0.05)$ leadership styles had a positive and significant relationship with retention of teachers. The relationship between laissez-faire leadership style $(\mathrm{r}=-0.291, p=0.005<0.05)$ was negative. The preliminary analysis suggested that transformational leadership correlated more with retention of teachers followed by the transactional leadership style.

The results in Table 5 showed that three leadership styles namely; transformational, transactional and laissez-faire leadership explained $25.2 \%$ of the variation in retention of teachers (adjusted $\mathrm{R}^{2}=0.252$ ). This meant that $74.8 \%$ was accounted for by other variables not considered in this model. The regression model was significant $(F=8.543, p=0.000<0.05)$. Nevertheless, of the three leadership styles, transformational leadership $(\beta=0.469, p=0.001<0.05)$ had a positive significant relationship with retention of teachers. Transactional leadership $(\beta=0.062, p=0.609>0.05)$ had a positive but insignificant relationship with retention of teachers but laissez-faire leadership $(\beta=-0.080, p=0.486>$ 0.05 ) had a negative and insignificant one.

\section{Discussion}

Data analysis revealed that retention of teachers in the private schools was good. This finding was inconsistent with the premise on which this study was based

Table 4. Correlation between leadership styles and retention of teachers.

\begin{tabular}{|c|c|c|c|c|}
\hline & $\begin{array}{c}\text { Retention of } \\
\text { Teachers }\end{array}$ & $\begin{array}{l}\text { Transformational } \\
\text { Leadership }\end{array}$ & $\begin{array}{l}\text { Transactional } \\
\text { Leadership }\end{array}$ & Laissez-Faire \\
\hline Retention of Teachers & 1 & & & \\
\hline $\begin{array}{l}\text { Transformational } \\
\text { Leadership }\end{array}$ & $\begin{array}{c}0.582^{\star *} \\
0.000\end{array}$ & 1 & & \\
\hline Transactional Leadership & $\begin{array}{c}0.269^{\star *} \\
0.009\end{array}$ & $\begin{array}{c}0.442^{* *} \\
0.000\end{array}$ & 1 & \\
\hline Laissez-Faire & $\begin{array}{c}-0.291^{\star *} \\
0.005\end{array}$ & $\begin{array}{c}-0.324^{\star *} \\
0.005\end{array}$ & $\begin{array}{l}0.040 \\
0.699\end{array}$ & 1 \\
\hline
\end{tabular}

Table 5. Regression of retention of teachers on leadership styles.

\begin{tabular}{ccc}
\hline \multirow{2}{*}{ Leadership Styles } & Standardised Coefficients & Significance \\
\cline { 2 - 3 } & Beta $(\beta)$ & $p$ \\
\hline Transformational Leadership & 0.469 & 0.001 \\
Transactional Leadership & 0.062 & 0.609 \\
Laissez-Faire & -0.080 & \\
Adjusted $\mathrm{R}^{2}=0.252$ & & \\
$\mathrm{~F}=8.543, p=0.000$ & & \\
\hline
\end{tabular}

a. Dependent variable: retention of teachers. 
that retention of teachers was low with only $16 \%$ of the teachers aspiring to stay which implied that $84 \%$ primary teachers in schools wanted to quit (Anguyo, 2014). These results suggested that in the private schools, retention of teachers was not a challenge. The study also found out that transformational leadership has a positive and significant relationship with retention of teachers. This finding was consistent with the findings of previous scholars. For instance, Caillier (2016) reported that there was a direct negative association between transformational leadership and turnover intentions. Also consistent with the finding of the study, in the inverse, Green et al. (2013), Gul et al. (2012), Gyensare et al. (2016), Sahu et al. (2018), and Wells and Peachey (2011) that transformational leadership was negatively related to turnover intention. However, on the contrary, Wanga and Yen (2014) reported that transformational leadership style was positively related to turnover intentions. Nevertheless, with the finding of the study consistent with the findings of previous scholars, it was deduced that transformational leadership related to retention of teachers.

The study, however, revealed that the relationship between transactional leadership and retention of teachers was positive but insignificant. Although in the inverse, this finding concurred with Maaitah (2018) and Sithole and Sudha (2014) who found out that the relationship between transactional leadership and employee turnover intention was positive and significant. However, the finding did not concur with Gul et al. (2012), Siew (2017), and Long et al. (2012) who reported that the association between leadership styles and turnover intentions was negative and insignificant. Nonetheless, with the finding agreeing with some of the scholars, it could be inferred that in schools in Uganda, transactional leadership did not have a significant relationship with retention of teachers. Last but not least, the finding that laissez-faire leadership had a negative and insignificant relationship with retention of teachers was not supported by previous scholars. For instance, Puni et al. (2016) reported that laissez faire leadership style indicated a significant negative relationship with turnover intentions. Similarly, Onsiro et al. (2016) found out a positive correlation between laissez faire leadership style and staff retention. Also, Wanga and Yen (2014) established that passive (laissez faire) leadership style was negatively related to turnover intentions. With the finding of the study not supported by all previous scholars, it was conjectured that in the context of schools in Uganda, laissez-faire leadership was less effective in motivating the retention of teachers.

\section{Conclusion}

The discussion above informed the conclusion that transformational leadership is imperative for retention of teachers. This is especially so if the head teacher assists teachers based on effort, recognises their achievements, behaves consistent with values, focuses on the strengths of teachers, promotes their development, encourages them to rethink ideas and provides them encouragement. Also, it is so if the head teacher encourages teachers to express ideas, encourages 
them to reason, instils pride in them, talks enthusiastically and talks about trusting each other. Further, it was concluded that transactional leadership is not the most probable leadership style for retention of teachers. This is because of its negative features like focusing on mistakes of teachers, tracking and monitoring mistakes, concentrating on failures and spending more time dealing with problems. Lastly, laissez-faire leadership is not a desirable leadership style due to its weaknesses including the head teacher reacting to problems only if serious, only if chronic, when there is failure and avoiding to decide. This is also because of head teachers avoiding involvement, delaying to respond and being unavailable when needed.

\section{Recommendations}

Drawing from the discussion above, it was recommended that head teachers who are the leaders in the schools should make it a priority to be transformational in their leadership. Thus, head teachers should assist teachers based on effort, recognise their achievements, behave consistent with values, focus on the strengths of teachers, promote their development, teachers to rethink ideas and provide them encouragement. Head teachers should also encourage teachers to express ideas, reason, instil pride in them, talk enthusiastically and promote trust. However, head teachers should limit their use of transactional leadership style. Therefore, they should not focus on mistakes of teachers, tracking and monitoring mistakes, concentrating on failures and spending more time dealing with problems. Finally, head teachers should avoid laissez-faire leadership by only reacting to problems only if serious, only if problems are chronic, when there is failure and not deciding. Head teachers should also not fail to be involved, not delay to respond and not be unavailable when needed.

\section{Conflicts of Interest}

The authors declare no conflicts of interest regarding the publication of this paper.

\section{References}

Akhtar, C. S., Aamir, A., Khurshid, M. A., Abro, M. M. Q., \& Hussain, J. (2015). Total Rewards and Retention: Case Study of Higher Education Institutions in Pakistan. Procedia-Social and Behavioral Sciences, 210, 251-259. https://doi.org/10.1016/j.sbspro.2015.11.365

Anguyo, I. (2014). 85\% of Ugandan Primary Teachers Want to Quit. New Vision. https://www.newvision.co.ug/new_vision/news/.../85-ugandan-primary-teachers-quit

Avolio, B. J. (1999). Full Leadership Development: Building the Vital Forces in Organisations. Thousand Oaks, CA: Sage.

Bass, B. M. (1998). Transformational Leadership: Industrial, Military, and Educational Impact. Mahwah, NJ: Lawrence Erlbaum Associates.

Blazar, D., \& Kraft, M. A. (2017). Teacher and Teaching Effects on Students' Attitudes and Behaviours. Educational Evaluation and Policy Analysis, 39, 146-170. https://doi.org/10.3102/0162373716670260 
Burgess, S. M. (2016). Human Capital and Education: The State of the Art in the Economics of Education. Burgess, Simon, Human Capital and Education: IZA Discussion Paper No. 9885. https://ssrn.com/abstract $=2769193$

Caillier, J. G. (2016). Do Transformational Leaders Affect Turnover Intentions and Extra-Role Behaviours through Mission Valence? American Review of Public Administration, 46, 226-242. https://doi.org/10.1177/0275074014551751

Cetin, M. O., \& Kinik, F. S. F. (2015). An Analysis of Academic Leadership Behavior from the Perspective of Transformational Leadership. Procedia-Social and Behavioral Sciences, 207, 519-527. https://doi.org/10.1016/j.sbspro.2015.10.122

Chambers, R., \& Hill, A. T. (2015). Teacher Preparation and Student Achievement in Personal Finance: Evidence from Keys to Financial Success. Perspectives on Economic Education Research, 9, 39-53.

Coetzee, M., Marx, A. A., \& Potgieter, I. L. (2017). Examining the Construct Validity of the Positive Coping Behavioural Inventory. SA Journal of Industrial Psychology, 43, 1-8. https://doi.org/10.4102/sajip.v43i0.1433

Darling-Hammond, L., Flook, L., Cook-Harvey, C., Barron, B., \& Osher, D. (2019). Implications for Educational Practice of the Science of Learning and Development. Applied Developmental Science, 1-44. https://doi.org/10.1080/10888691.2018.1537791

Day, D. V., \& Antonakis, J. (2012). The Nature of Leadership. Los Angeles, CA: Sage

De Bono, S., Remme, J., \& Jones, S. (2008). Leadership, Change and Responsibility. Oxford: Meyer \& Meyer Media.

Dell'Aquila, E., Marocco, D., \& Ponticorvo, M. (2016). Educational Games for Soft-Skills Training in Digital Environments: New Perspectives. Bern: Springer Nature. https://doi.org/10.1007/978-3-319-06311-9

Deshwal, S. (2015). Employee Retention: Perspective of Employees. International Journal of Applied Research, 1, 344-345.

Dolton, P., \& Newson, D. (2003). The Relationship between Teacher Turnover and School Performance. London Review of Education, 1, 131-140. https://doi.org/10.1080/14748460306685

Eagly, A. H., Johannesen-Schmidt, M. C., \& Van Engen, M. L. (2003). Transformational, Transactional, and Laissez-Faire Leadership Styles: A Meta-Analysis Comparing Women and Men. Psychological Bulletin, 129, 569-591. https://doi.org/10.1037/0033-2909.129.4.569

Foster, D. (2018). Teacher Recruitment and Retention in England. Briefing Paper No. 7222.

Gibbons, S., Scrutinio, V., \& Telhaj, S. (2018). Teacher Turnover: Does It Matter for Pupil Achievement? EP Discussion Paper No. 1530. Centre for Economic Performance.

Ginsburg, M. (2017). Teachers as Human Capital or Human Beings? USAID's Perspective on Teachers. Current Issues in Comparative Education, 20, 6-30.

Giorgi, G., Shoss, M., \& Di Fabio, A. (2017). From Organisational Welfare to Business Success: Higher Performance in Healthy Organisational Environments. Lausanne: Frontiers Media SA. https://doi.org/10.3389/978-2-88945-315-3

Gosling, J., \& Jones, S. (2012). Key Concepts in Leadership. Los Angeles, CA: Sage Publications Ltd. https://doi.org/10.4135/9781473914759

Gözükara, İ., \& Şimşek, O. F. (2015). Linking Transformational Leadership to Work Engagement and the Mediator Effect of Job Autonomy: A Study in a Turkish Private Non-PROFIT University. Procedia-Social and Behavioral Sciences, 195, 963-971. https://doi.org/10.1016/j.sbspro.2015.06.274 
Green, A. E., Miller, E. A., \& Aarons, G. A. (2013). Transformational Leadership Moderates the Relationship between Emotional Exhaustion and Turnover Intention among Community Mental Health Providers. Community Mental Health Journal, 49, 373-379. https://doi.org/10.1007/s10597-011-9463-0

Griffin, D. (2013). Education Reform: The Unwinding of Intelligence and Creativity. Heidelberg: Springer.

Gul, S., Ahmad, B., Ur Rehman, S., Shabir, N., \& Razzaq, N. (2012). Leadership Styles, Turnover Intentions and the Mediating Role of Organizational Commitment. Information and Knowledge Management, 2, 44-51.

Gyensare, M. A., Olivia Anku-Tsede, O., Sanda, M., \& Okpoti, C. A. (2016). Transformational Leadership and Employee Turnover Intention: The Mediating Role of Affective Commitment. World Journal of Entrepreneurship, Management and Sustainable Development, 12, 243-266. https://doi.org/10.1108/WJEMSD-02-2016-0008

Hornáčková, V., Hálová, K., \& Nechanická, V. (2015). Analysis of Democratic Leadership Style of Nursery Schools/Kindergartens. Procedia-Social and Behavioral Sciences, 171, 717-723. https://doi.org/10.1016/j.sbspro.2015.01.183

Ismail, A., Mohamad, M. H., Mohamed, H. A. B., Rafiuddin, N. M., \& Zhen, K. W. P. (2010). Transformational and Transactional Leadership Styles as a Predictor of Individual Outcomes. Theoretical \& Applied Economics, 17.

Junarso, T. (2009). Leadership Greatness: Best Practices to Become a Great Leader. New York: iUniverse.

Kanste, O., Miettunen, J., \& Kyngäs, H. (2007). Psychometric Properties of the Multifactor Leadership Questionnaire among Nurses. Journal of Advanced Nursing, 57, 201-212. https://doi.org/10.1111/j.1365-2648.2006.04100.x

Kanste, O., Miettunen, J., \& Kyngäs, H. (2007). Psychometric Properties of the multifactor Leadership Questionnaire among Nurses. Journal of Advanced Nursing, 57, 201-212. https://doi.org/10.1111/j.1365-2648.2006.04100.x

Kossivi, B., Xu, M., \& Kalgora, B. (2016). Study on Determining Factors of Employee Retention. Open Journal of Social Sciences, 4, 261-268.

https://doi.org/10.4236/jss.2016.45029

Krishnan, V. R. (2012). Transformational Leadership and Personal Outcomes: Empowerment as Mediator. Leadership \& Organization Development Journal, 33, 550-563. https://doi.org/10.1108/01437731211253019

Kyndt, E., Dochy, F., Michielsen, M., \& Moeyaert, B. (2009). Employee Retention: Organisational and Personal Perspectives. Vocations and Learning, 2, 195-215.

https://doi.org/10.1007/s12186-009-9024-7

Lewin, K., Lippit, R., \& White, R. K. (1939). Patterns of Aggressive Behaviour in Experimentally Created Social Climates. Journal of Social Psychology, 10, 271-301. https://doi.org/10.1080/00224545.1939.9713366

Lindgreen, A., Palmer, R., Wetzels, M., \& Antioco, M. (2009). Do Different Marketing Practices Require Different Leadership Styles? An Exploratory Study. Journal of Business \& Industrial Marketing, 24, 14-26. https://doi.org/10.1108/08858620910923667

Long, C. S., Thean, L. Y., Ismail, W. K. W., \& Jusoh, A. (2012). Leadership Styles and Employees' Turnover Intention: Exploratory Study of Academic Staff in a Malaysian College. World Applied Sciences Journal, 19, 575-581.

Maaitah, A. M. (2018). The Role of Leadership Style on Turnover Intention. International Review of Management and Marketing, 8, 24.

Mehta, M., Kurbetti, A., \& Dhankhar, R. (2014). Review Paper Study on Employee Reten- 
tion and Commitment. International Journal of Advance Research in Computer Science and Management Studies, 2, 154-164.

Ministry of Education and Sport [MoES] (2013). Teacher Issues in Uganda: A Shared Vision for an Effective Teachers' Policy. Kampala: MoES.

Moorosi, P., \& Bantwini, B. D. (2016). School District Leadership Styles and School Improvement: Evidence from Selected School Principals in the Eastern Cape Province. South African Journal of Education, 36, 1-9. https://doi.org/10.15700/saje.v36n4a1341

Nikezić, S., Purić, S., \& Purić, J. (2012). Transactional and Transformational Leadership: Development through Changes. International Journal for Quality Research, 6, 285-296.

Onsiro, M. R., Namatovu, L. A., \& Babu, M. J. (2016). Analysis of the Effect of Leadership Styles on Staff Retention in Selected Private Hospitals in Kampala District, Uganda. European Journal of Business and Management, 8, 141-150.

Özoglu, M. (2015). Mobility-Related Teacher Turnover and the Unequal Distribution of Experienced Teachers in Turkey. Educational Sciences: Theory and Practice, 15, 891-909. https://doi.org/10.12738/estp.2015.4.2619

Puni, A., Agyemang, C. B., \&Asamoah, E. S. (2016). Leadership Styles, Employee Turnover Intentions and Counterproductive Work Behaviours. International Journal of Innovative Research \& Development, 5, 1-7.

Rodríguez, F. J. (2009). The Impact of Teacher Retention on Student Achievement in High School Mathematics. PhD Dissertation, Boca Raton, FL: Florida Atlantic University.

Ronfeldt, M., Loeb, S., \& Wyckoff, J. (2013). How Teacher Turnover Harms Student Achievement. American Educational Research Journal, 50, 4-36.

https://doi.org/10.3102/0002831212463813

Rothfelder, K., Ottenbacher, M. C., \& Harrington, R. J. (2012). The Impact of Transformational, Transactional and Non-Leadership Styles on Employee Job Satisfaction in the German Hospitality Industry. Tourism and Hospitality Research, 12, 201-214. https://doi.org/10.1177/1467358413493636

Sahu, S., Pathardikar, A., \& Kumar, A. (2018). Transformational Leadership and Turnover: Mediating Effects of Employee Engagement, Employer Branding, and Psychological Attachment. Leadership \& Organization Development Journal, 39, 82-99. https://doi.org/10.1108/LODJ-12-2014-0243

Siew, L. K. (2017). Analysis of the Relationship between Leadership Styles and Turnover Intention within Small Medium Enterprise in Malaysia. Journal of Arts \& Social Sciences, 1, 1-11.

Sithole, A., \& Sudha, S. (2014). Transactional Leadership Style and Employees' Turnover Intention in Information Technology Organizations. International Journal of Case Studies, 3, 78-82. https://ssrn.com/abstract=2875957

Srivastava, O. P. (2018). Bhagavad Gita: The Art and Science of Management for the 21st Century. New Delhi: Zorba Books.

Stillo, S., \& Furxhi, G. (2016). The Retention of the Employees as Long as Possible in the Organization, through Finding the Right Factors of Motivation. Albania as a Case of Study. European Journal of Economics and Business Studies, 2, 51-58. https://doi.org/10.26417/ejes.v5i1.p51-58

Sutcher, L., Darling-Hammond, L., \& Carver-Thomas, D. (2016). A Coming Crisis in Teaching? Teacher Supply, Demand, and Shortages in the U.S. Palo Alto, CA: Learning Policy Institute

Symeonidis, V. (2015). The Status of Teachers and the Teaching Profession: A Study of Education Unions Perspectives. Brussels: Education International Research Institute. 
Tarsik, N. F., Kassim, N. A., \& Nasharudin, N. (2014). Transformational, Transactional or Laissez-Faire: What Styles Do University Librarians Practice? Journal of Organizational Management Studies, 2014, Article ID: 194100. https://doi.org/10.5171/2014.194100

Tavakol, M., \& Dennick, R. (2011). Making Sense of Cronbach's Alpha. International Journal of Medical Education, 2, 53-55. https://doi.org/10.5116/ijme.4dfb.8dfd

Tibagwa, K. N., Onen, D., \& Oonyu, J. (2016). Head Teacher's Leadership Styles and the Quality of Teacher Support Supervision. International Journal of Education and Research, 4, 63-78.

Waldman, D. A., Ramirez, G. G., House, R. J., \& Puranam, P. (2001). Does Leadership Matter? CEO Leadership Attributes and Profitability under Conditions of Perceived Environmental Uncertainty. Academy of Management Journal, 44, 134-143.

https://doi.org/10.5465/3069341

Wang, H., \& Guan, B. (2018). The Positive Effect of Authoritarian Leadership on Employee Performance: The Moderating Role of Power Distance. Frontiers in Psychology, 9, 1-10. https://doi.org/10.3389/fpsyg.2018.00357

Wanga, C., \& Yen, C. (2014). Leadership and Turnover Intentions of Taiwan TV Reporters: The Moderating Role of Safety Climate. Asian Journal of Communication, 25, 255-270. https://doi.org/10.1080/01292986.2014.960877

Wells, J. E., \& Peachey, J. W. (2011). Turnover Intentions: Do Leadership Behaviours and Satisfaction with the Leader Matter? Team Performance Management: An International Journal, 17, 23-40. https://doi.org/10.1108/13527591111114693

Xenikou, A. (2017). Transformational Leadership, Transactional Contingent Reward, and Organizational Identification: The Mediating Effect of Perceived Innovation and Goal Culture Orientations. Frontiers in Psychology, 8, 1754.

https://doi.org/10.3389/fpsyg.2017.01754 


\section{Appendix: Questionnaire}

\begin{tabular}{|c|c|c|}
\hline Construct & Item & \\
\hline \multirow[t]{6}{*}{$\begin{array}{l}\text { Section A: Background Characteristics } \\
\text { (BV) }\end{array}$} & & Measures \\
\hline & BV1 & Sex (male, female) \\
\hline & BV2 & Age groups in years (Up to 29 years, 30 - 39 years, $40-39$ years, 50 years and above) \\
\hline & BV3 & Marital status (single, married, widowed, divorced) \\
\hline & BV4 & $\begin{array}{l}\text { Highest level of education attained by the respondent (certificate, diploma, bachelor's degree, } \\
\text { post graduate qualifications) }\end{array}$ \\
\hline & BV15 & Experience (less than 5 years, 5 - 10 years, 10 years and above) \\
\hline \multirow[t]{12}{*}{ Section B: Retention of Teachers (RT) } & & Measures \\
\hline & RT1 & I love working for this school \\
\hline & RT2 & I see a future for myself within this school \\
\hline & RT3 & If I wanted to do another job or function, I would look first at the possibilities within this school \\
\hline & RT4 & I have checked out a job in another school previously \\
\hline & RT5 & If I received an attractive job offer from another school, I would take the job \\
\hline & RT6 & If I could start over again, I would choose to work for another school \\
\hline & RT7 & If it were up to me, I will definitely be working for this school for the next five years \\
\hline & RT8 & The work I am doing is very important to me \\
\hline & RT9 & Within this school, my work gives me satisfaction \\
\hline & RT10 & It does not matter if I am working for this school or another, as long as I have work \\
\hline & RT11 & I am planning on working for another school within a period of three years \\
\hline Section: Leadership Styles & & Measures \\
\hline \multirow[t]{17}{*}{ Transformational Leadership (TL) } & LT1 & My head teacher assists based on effort \\
\hline & LT2 & My head teacher recognizes my achievements \\
\hline & LT3 & My head teacher behaves consistent with values \\
\hline & LT4 & My head teacher focuses my strengths \\
\hline & LT5 & My head teacher promotes development \\
\hline & LT6 & My head teacher provides reassurance overcoming obstacles \\
\hline & LT7 & My head teacher encourages non-traditional thinking \\
\hline & LT8 & My head teacher provides advice for development \\
\hline & LT9 & My head teacher encourages us to rethink ideas \\
\hline & LT10 & My head teacher clarifies rewards \\
\hline & LT11 & My head teacher provides encouragement \\
\hline & LT12 & My head teacher encourages us to express ideas \\
\hline & LT13 & My head teacher encourages reasoning \\
\hline & LT14 & My head teacher instils pride in me \\
\hline & LT15 & My head teacher treats us as individuals \\
\hline & LT16 & My head teacher talks enthusiastically \\
\hline & LT17 & My head teacher talks about trusting each other \\
\hline
\end{tabular}




\section{Continued}

\begin{tabular}{|c|c|c|}
\hline \multirow[t]{8}{*}{ Transactional Leadership (TR) } & TR1 & My head teacher focuses on my mistakes \\
\hline & TR2 & My head teacher tracks and monitors my mistakes \\
\hline & TR3 & My head teacher concentrates on failures \\
\hline & TR4 & My head teacher puts spends more time dealing with problems \\
\hline & TR5 & My head teacher assists basing on the effort of the individual teacher \\
\hline & TR6 & My head teacher rewards my achievement \\
\hline & TR7 & My head teacher recognizes my achievement \\
\hline & TR8 & My head teacher clarifies rewards \\
\hline \multirow[t]{7}{*}{ Laissez-Faire Leadership (LL) } & LL1 & My head teacher reacts to problems, only if serious \\
\hline & LL2 & My head teacher reacts to problems, only if chronic \\
\hline & LL3 & My head teacher reacts to failure \\
\hline & LL4 & My head teacher avoids deciding \\
\hline & LL5 & My head teacher avoids involvement \\
\hline & LL6 & My head teacher delays responding \\
\hline & LL7 & My head teacher is unavailable when needed \\
\hline
\end{tabular}

